FROM THE EDITORS' DESK

\title{
The Art of Medicine: JGIM Introduces Sketchbook
}

\author{
Audrey Young, $\mathrm{MD}^{7}$, Anna Reisman, $\mathrm{MD}^{2}$, and Jeremy Graham, DO, $M A^{3}$ \\ ${ }^{1}$ Evergreen Hospital and Medical Center, Kirkland, WA, USA; ${ }^{2}$ Yale University School of Medicine, New Haven, CT, USA; ${ }^{3} \mathrm{CHASH}$ Health, Spokane, WA, \\ USA.
}

J Gen Intern Med 34(7):107 1

DOI: $10.1007 / \mathrm{s} 11606-018-4799-6$

(c) Society of General Internal Medicine 2019

$\mathrm{B}$ usy physicians employ all manner of tricks to capture the essence of each patient in the medical record. Some include personal details_-granddaughter's wedding approaching, loves to fish with dog Tuffy, walks to wife's grave every day. Before electronic charts became the norm, Dr. Alan Blum sketched quick renditions of his patients to capture an expression, a gesture, a feeling. Readers may see parallels to the physician-poet William Carlos Williams, who, in the tiny space between one patient and the next, would jot down a line or two of description or dialogue in his notebook.

We are pleased to feature four sketches from Dr. Alan Blum in the inaugural publication of the Healing Arts category Sketchbook. Collected from volumes of as-yet unprinted images, Dr. Blum offers here "Patient Ladies," four annotated drawings of women that capture a moment. Readers may also enjoy some of his other published brief clinical portraits. ${ }^{1}$

Drawing serves both artist and viewer. For the artist, drawing slows us down, helps us observe more closely. The viewer must also pause, think, examine, notice. A growing body of data suggests that art observation enhances skills crucial to physical examination and diagnosis. ${ }^{2,3}$ Many medical schools now provide a variety of exercises in museums, as a means of improving skills of perception as well as one's descriptive language, and often as a way to stimulate discussion of the artist's intent and effect.
Sketchbook is a new platform for JGIM readership to enjoy, contemplate, and offer their own visual art to a clinical audience. Sketchbook invites single-page submissions of blackand-white art from technical photo realism to evocative doodles, from portrait to anatomic observation, from comic book art to landscapes. Graphic novelist Marjane Satrapi asserted that "drawing [is the] first language of human beings, before writing." Pictures and abstracted symbols convey meaning; one sees a thing before assigning words and names. Sketchbook is to be an avenue for just such "meaning-making," presenting physician and patient drawings as a tool of resilience, fortification against burnout, and a means to express the joy of caring for human beings.

Corresponding Author: Jeremy Graham, DO, MA; CHAS Health, Spokane, WA, USA (e-mail:jdg4im@gmail.com).

Publisher's Note: Springer Nature remains neutral with regard to jurisdictional claims in published maps and institutional affiliations.

\section{REFERENCES}

1. Blum A. Gentle Men. Hektoen International, A Journal of Medical Humanties. 2012;4(1). Winter. ISSN 2155-3017 http://hekint.org/2017/ 01/22/gentle-men/. Accessed 26 Nov 2018.

2. Dolev JC, Friedlander LK, Braverman IM. Use of fine art to enhance visual diagnostic skills. JAMA. 2001;286:1020-102.

3. Naghshineh S, Hafler JP, Miller AR, et al. Formal art observation training improves medical students' visual diagnostic skills J Gen Intern Med. 2008;23:991-997.

4. Satrapi M. Interview with Jeffrey Brown "PBS NewsHour" August 17, 2012, Accessed October 2018 at: https://www.pbs.org/newshour/arts/ conversation-marjane-satrapi. 